\title{
Penerapan Penyajian Laporan Keuangan Berdasarkan SAK-ETAP Untuk Mengetahui Kinerja Keuangan UMKM Toko Angka Wijaya
}

\author{
Aprilia Kartika dan Airin Nuraini \\ Program Studi Akuntansi, Institut Bisnis dan Informatika Kesatuan \\ Bogor, Indonesia
}

E-Mail: apriliakrtka@gmail.com
Submitted: JANUARI 2020

Accepted: APRIL 2020

\section{ABSTRACT}

Small and Medium Micro Enterprises are businesses that have an important role in the economy in Indonesia because micro, small and medium enterprises aim to grow and develop their business in order to build a national economy. SMEs are also able to open new jobs for domestic workers, SMEs provide income for the country in the form of foreign exchange. To get a better $U M K M$, so that SMEs can compete with large business institutions in terms of economy and empowerment, SMES actors must be aware of the importance of applying financial statements. The purpose of this study was to find out how the application of financial statements based on $S A K-E T A P$ on SMEs and how financial performance in SMEs was implemented. The author conducts research at the Wijaya Figures Store UMKM located on Jl. Endang Sumawijaya Kampung Sindang Barang, Bogor Regency. This research method uses a qualitative descriptive method. The results of the Angka Wijaya SMES research did not apply financial statement. This is because the SMES owner Angka Wijaya do not understand the financial statements based on SAK ETAP. During 2018 total assets, liability+equitycan be generated in the amount of IDR 386,558,000, profit of IDR 120,518,000 equity of IDR 366,229,000 and total net cash flow of IDR $261,238,000$. The results of the wijaya store SMEs performance are calculated using profitability ratios based on profit from good sales and ussing on asset, meaning that the angka wijaya UMKMs are good in terms of sales and efficient in using assets, while SMES performance in capital usage is not good because of UMKM Angka wijaya is less efficient in capital

Keywords: application of financial statement presentation based on sak-etap to know wijaya's financial performance in figures shop smes

\section{PENDAHULUAN}

Usaha Mikro kecil dan Menengah merupakan suatu usaha yang mempunyai peran penting dalam perekonomian di Indonesia karena usaha mikro, kecil menengah bertujuan menumbuhkan dan mengembangkan usahanya dalam rangka membangun perekonomian nasional, membuka lapangan pekerjaan dan memberikan pendapatan dalam bentuk devisa bagi negara. Untuk menuju UMKM yang lebih lebih baik, sehingga UMKM dapat bersaing dengan lembaga bisnis besar dalam hal ekonomi dan pemberdayaannya, maka para pelaku UMKM harus menyadari pentingnya penerapan laporan keuangan. IAI pada tanggal 17 Juli 2009, telah menerbitkan SAK untuk Entitas tanpa Akuntabilitas Publik (SAK-ETAP). dengan diterbitkannya SAK-ETAP diharapkan dapat memberikan kemudahan untuk UMKM dalam menyajikan laporan keuangan. Tetapi, masih banyak para pelaku UMKM yang tidak mengerti bagaimana penerapan penyajian laporan keuangan berdasarkan SAK-ETAP kebanyakan UMKM hanya melakukan pencatatan atau pembukuan keuangan sederhana.

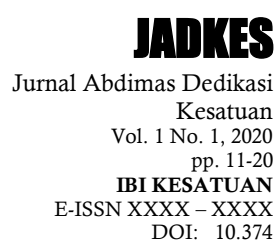


SAK-ETAP and

Financial

Performance

$\underline{12}$

\section{JADKES}

Jurnal Abdimas Dedikasi Kesatuan

Vol. 1 No. 1, 2020

pp. $11-20$

IBI KESATUAN

E-ISSN XXXX - XXXX

DOI:
Berdasarkan latar belakang tersebut, maka tujuan dari kegiatan pengabdian kepada masyarakat ini adalah:

1. Untuk mendampingi aplikasi atau penerapan penyajian laporan keuangan berdasarkan SAK-ETAP pada UMKM Toko Angka Wijaya.

2. Untuk mengetahui bagaimana kinerja keuangan pada UMKM Toko Angka Wijaya.

Menurut Kieso dan Weygandt (2010;2) "Laporan keuangan adalah sarana pengkomunikasian informasi keuangan utama kepada pihak pihak di luar perusahaan", sedangkan menurut Efraim (2012;37)"Laporan keuangan adalah suatu penyajian terstuktur mengenai posisi keuangan dan kinerja keuangan suatu entitas" dan menurut Hans Kartikahadi, dkk $(2012 ; 12)$ "Laporan keuangan adalah media utama bagi suatu entitas untuk mengkomunikasikan informasi keuangan oleh manajemen kepada para pemangku kepentingan". Dari pendapat para ahli tersebut dapat disimpulkan bahwa pengertian laporan keuangan adalah sebuah informasi yang menggambarkan kinerja dan kondisi keungan perusahaan yang ditunjukan kepada yang berkepentingan.

Dalam SAK-ETAP (BAB2) tujuan laporan keuangan adalah: Menyediakan informasi posisi keuangan, kinerja keuangan, dan laporan arus kas suatu entitas yang bermanfaat bagi sejumlah besar pengguna dalam pengambilan keputusan ekonomi oleh siapapun yang tidak dalam posisi dapat meminta laporan keuangan khusus untuk memenuhi informasi kebutuhan tertentu.

Karakteristik laporan keuangan berdasarkan Standar Akuntansi Keuangan Entitas Tanpa Akuntabilitas Publik (BAB 2) adalah: Dapat Dipahami, Relevan, Materialitas, Keandalan, Substansi Mengungguli Bentuk, Pertimbangan Sehat, Kelengkapan, Dapat Dibandingkan, Tepat Waktu, Keseimbangan antara Biaya dan Manfaat

Entitas yang laporan keuangannya mematuhi SAK ETAP harus membuat suatu pernyataan eksplisit dan secara penuh (explicit and unreserved statement) atas kepatuhan tersebut dalam catatan atas laporan keuangan. Laporan keuangan tidak boleh menyatakan mematuhi SAK ETAP kecuali jika mematuhi semua persyaratan dalam SAK ETAP.

\section{METODE PELAKSANAAN}

Kegiatan identifikasi obyek mengawali kegiatan pengabdian kepada masyarakat ini, yang dilanjutkan dengan tahapan persiapan data dan perlengkapan yang digunakan untuk pendampingan, pelaksanaan pendampingan dilakukan lalu di akhir kegiatan, proses monitoring dan evaluasi dilakukan untuk memastikan bahwa kegiatan pengabdian kepada masyarakat telah berdampak nyata terhadap obyek kegiatan.

Kegiatan pengabdian kepada masyarakat ini dilaksanakan UMKM Toko Angka Wijaya. Toko Angka Wijaya merupakan salah satu UMKM yang menjual bahan baku sepatu dan sandal milik Bapak Jajang apid yang sudah berdiri sejak 2011 dan memiliki 1 orang karyawan dan dibantu oleh istrinya. Toko Angka Wijaya berada Kampung Sindang Barang, dimana kampung Sindang Barang adalah kampung yang sebagian besar masyarakatnya adalah pelaku bisnis di bidang pembuatan sepatu dan sandal sehingga UMKM Toko Angka Wijaya dapat memperoleh omzet lebih dari Rp300.000.000 pertahun

Kegiatan pengabdian kepada masyarakat ini dilakukan setelah proses komunikasi melalui surat menyurat yang akhirnya diperoleh kesepakatan bersama dilakukannya pendampingan. Kegiatan dilaksanakan pada bulan April sampai dengan Agustus 2019. Untuk mendukung tercapainya hasil pendampingan tersebut, hal yang telah dilakukan adalah dengan melakukan studi lapangan langsung pada objek yang akan diteliti, menganalisis pencatatan keuangan sederhana yang dilakukan UMKM dan informasi lainnya seperti faktur pembelian dan penjualan yang dimiliki UMKM untuk dibuat jurnal umum kemudian diposting ke dalam buku besar dan melakukan penyusunan laporan keuangan berdasarkan SAK ETAP agar mengetahui kinerja keuangannya dengan cara menghitung rasio profitabilitas dari laporan keuangan yang telah disusun tersebut. Pendampingan penerapannya dilakukan kemudian kepada pelaku UMKM 
dengan cara menjelaskan dan memberi contoh untuk kemudian diikuti oleh pelaku UMKM dimaksud.

\section{PEMBAHASAN}

\section{Penerapan Laporan Keuangan Berdasarkan SAK ETAP pada UMKM Toko Angka Wijaya}

Dari hasil penelitian, UMKM Angka Wijaya bergerak di bidang perusaahaann dagang yang menjual bahan baku sepatu dan sandal. UMKM Toko Angka Wijaya tidak memiliki Laporan Keuangan atas kegiatan usahanya. Pemilik UMKM hanya melakukan pencatatan atau pembukuan keuangan sederhana dalam usahanya. Karena, UMKM toko angka wijaya hal ini di karenakan pemilik UMKM Toko Angka Wijaya tidak mengerti mengenai Akuntansi. Laporan keuangan disusun berdasarkan siklus akuntansi. Berikut ini adalah hasil siklus akuntansi dari mulai jurnal sampai dengan laporan keuangan :

1. Siklus skuntansi selama periode berjalan:

a. Transaksi - UMKM toko Angka wijaya sudah melakukan pencatatan transaksi secara sederhana

b. Pencatatan Penjurnalan - Dalam hal penjurnalan UMKM Toko Angka Wijaya belum melakukannya, untuk itu dilakukan pencatatan penjurnalan atas transaksi UMKM Toko Angka Wijaya. Jurnal yang digunakan adalah jurnal khusus.

\section{UMKM Toko Angka Wijaya \\ JURNAL KHUSUS}

Untuk Periode Yang Berakhir Pada Desember 2018

1. Jurnal Penerimaan Kas

\begin{tabular}{|c|c|c|c|c|c|c|}
\hline \multirow{2}{*}{ Bulan } & \multirow[t]{2}{*}{ Deskripsi } & \multirow{2}{*}{\multicolumn{2}{|c|}{$\begin{array}{l}\text { Debit } \\
\text { Kas }\end{array}$}} & \multicolumn{3}{|l|}{ Kredit } \\
\hline & & Kas & & Penjua & & Piutang Dagang \\
\hline \multirow[t]{3}{*}{ Januari } & Irah & $\mathrm{Rp}$ & 11.797 .500 & $\mathrm{Rp}$ & 11.797 .500 & \\
\hline & Usman & $\mathrm{Rp}$ & 3.495 .000 & $\mathrm{Rp}$ & 3.495 .000 & \\
\hline & Pembeli Lain & $\mathrm{Rp}$ & 6.725 .500 & $\mathrm{Rp}$ & 6.725 .500 & \\
\hline \multirow[t]{3}{*}{ Februari } & Irah & $\mathrm{Rp}$ & 5.468 .000 & $\mathrm{Rp}$ & 5.468 .000 & \\
\hline & Usman & $\mathrm{Rp}$ & 3.278 .000 & $\mathrm{Rp}$ & 3.278 .000 & \\
\hline & Pembeli Lain & $\mathrm{Rp}$ & 4.180 .000 & $\mathrm{Rp}$ & 4.180 .000 & \\
\hline \multirow[t]{3}{*}{ Maret } & Irah & $\mathrm{Rp}$ & 11.095 .500 & $\mathrm{Rp}$ & 11.095 .500 & \\
\hline & Usman & $\mathrm{Rp}$ & 1.036 .000 & $\mathrm{Rp}$ & 1.036 .000 & \\
\hline & Pembeli Lain & $\mathrm{Rp}$ & 5.265 .000 & $\mathrm{Rp}$ & 5.265 .000 & \\
\hline \multirow[t]{4}{*}{ April } & Irah & $\mathrm{Rp}$ & 7.121 .500 & $\mathrm{Rp}$ & 7.121 .500 & \\
\hline & Usman & $\mathrm{Rp}$ & 4.120 .000 & $\mathrm{Rp}$ & 4.120 .000 & \\
\hline & Sodor & $\mathrm{Rp}$ & 1.029 .000 & $\mathrm{Rp}$ & 1.029 .000 & \\
\hline & Pembeli Lain & $\mathrm{Rp}$ & 5.305 .000 & $\mathrm{Rp}$ & 5.305 .000 & \\
\hline \multirow[t]{4}{*}{ Mei } & Irah & $\mathrm{Rp}$ & 5.166 .000 & $\mathrm{Rp}$ & 5.166 .000 & \\
\hline & Usman & $\mathrm{Rp}$ & 11.000 .000 & $\mathrm{Rp}$ & 11.000 .000 & \\
\hline & Sodor & $\mathrm{Rp}$ & 15.770 .500 & $\mathrm{Rp}$ & 15.770 .500 & \\
\hline & Pembeli Lain & $\mathrm{Rp}$ & 4.700 .000 & $\mathrm{Rp}$ & 4.700 .000 & \\
\hline \multirow[t]{6}{*}{ Juni } & Usman & $\mathrm{Rp}$ & 15.000 .000 & & & $\mathrm{Rp} 15.000 .000$ \\
\hline & Irah & $\mathrm{Rp}$ & 3.437 .000 & $\mathrm{Rp}$ & 3.437 .000 & \\
\hline & Usman & $\mathrm{Rp}$ & 1.763 .000 & $\mathrm{Rp}$ & 1.763 .000 & \\
\hline & Koko & $\mathrm{Rp}$ & 2.196 .000 & $\mathrm{Rp}$ & 2.196 .000 & \\
\hline & Sodor & $\mathrm{Rp}$ & 6.643 .000 & $\mathrm{Rp}$ & 6.643 .000 & \\
\hline & Pembeli Lain & $\mathrm{Rp}$ & 4.910 .000 & $\mathrm{Rp}$ & 4.910 .000 & \\
\hline \multirow[t]{5}{*}{ Juli } & Sodor & $\mathrm{Rp}$ & 15.219 .500 & & & Rp 15.219.500 \\
\hline & Irah & $\mathrm{Rp}$ & 2.978 .000 & $\mathrm{Rp}$ & 2.978 .000 & \\
\hline & Koko & $\mathrm{Rp}$ & 3.534 .000 & $\mathrm{Rp}$ & 3.534 .000 & \\
\hline & Sodor & $\mathrm{Rp}$ & 6.940 .500 & $\mathrm{Rp}$ & 6.940 .500 & \\
\hline & Pembeli Lain & $\mathrm{Rp}$ & 4.465 .000 & $\mathrm{Rp}$ & 4.465 .000 & \\
\hline \multirow[t]{5}{*}{ Agustus } & Irah & $\mathrm{Rp}$ & 6.068 .000 & $\mathrm{Rp}$ & 6.068 .000 & \\
\hline & Fendi & $\mathrm{Rp}$ & 72.625 .500 & $\mathrm{Rp}$ & 72.625 .500 & \\
\hline & Koko & $\mathrm{Rp}$ & 10.718 .000 & $\mathrm{Rp}$ & 10.718 .000 & \\
\hline & Sodor & $\mathrm{Rp}$ & 7.824 .000 & $\mathrm{Rp}$ & 7.824 .000 & \\
\hline & Pembeli Lain & $\mathrm{Rp}$ & 4.250 .000 & $\mathrm{Rp}$ & 4.250 .000 & \\
\hline \multirow[t]{6}{*}{ September } & Fendi & $\mathrm{Rp}$ & 500.000 & & & Rp 500.000 \\
\hline & Irah & $\mathrm{Rp}$ & 10.908 .000 & $\mathrm{Rp}$ & 10.908 .000 & \\
\hline & Fendi & $\mathrm{Rp}$ & 3.378 .500 & $\mathrm{Rp}$ & 3.378 .500 & \\
\hline & Koko & $\mathrm{Rp}$ & 10.807 .000 & $\mathrm{Rp}$ & 10.807 .000 & \\
\hline & Sodor & $\mathrm{Rp}$ & 5.604 .000 & $\mathrm{Rp}$ & 5.604 .000 & \\
\hline & Pembeli Lain & $\mathrm{Rp}$ & 4.630 .000 & $\mathrm{Rp}$ & 4.630 .000 & \\
\hline
\end{tabular}

SAK-ETAP and Financial Performance

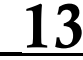


SAK-ETAP and Financial Performance

\section{4}

\section{JADKES}

Jurnal Abdimas Dedikasi Kesatuan

Vol. 1 No. 1, 2020

pp. $11-20$

IBI KESATUAN

E-ISSN XXXX - XXXX

DOI:

\begin{tabular}{|c|c|c|c|c|c|c|}
\hline Oktober & Irah & $\mathrm{Rp}$ & 7.557 .800 & $\mathrm{Rp}$ & 7.557 .800 & \\
\hline \multirow[t]{4}{*}{ Oktober } & Fendi & $\mathrm{Rp}$ & 15.661 .500 & $\mathrm{Rp}$ & 15.661 .500 & \\
\hline & Koko & $\mathrm{Rp}$ & 11.759 .000 & $\mathrm{Rp}$ & 11.759 .000 & \\
\hline & Sodor & $\mathrm{Rp}$ & 2.182 .000 & $\mathrm{Rp}$ & 2.182 .000 & \\
\hline & Pembeli Lain & $\mathrm{Rp}$ & 4.955 .000 & $\mathrm{Rp}$ & 4.955 .000 & \\
\hline \multirow[t]{4}{*}{ Nopember } & Irah & $\mathrm{Rp}$ & 3.610 .000 & $\mathrm{Rp}$ & 3.610 .000 & \\
\hline & Fendi & $\mathrm{Rp}$ & 3.172 .000 & $\mathrm{Rp}$ & 3.172 .000 & \\
\hline & Koko & $\mathrm{Rp}$ & 10.674 .000 & $\mathrm{Rp}$ & 10.674 .000 & \\
\hline & Pembeli Lain & $\mathrm{Rp}$ & 4.775 .000 & $\mathrm{Rp}$ & 4.775 .000 & \\
\hline \multirow[t]{5}{*}{ Desember } & Koko & $\mathrm{Rp}$ & 12.034 .500 & & & Rp 12.034.500 \\
\hline & Irah & $\mathrm{Rp}$ & 32.664 .000 & & & Rp 32.664.000 \\
\hline & Fendi & $\mathrm{Rp}$ & 2.000 .000 & & & Rp $\quad 2.000 .000$ \\
\hline & Koko & $\mathrm{Rp}$ & 3.969 .000 & $\mathrm{Rp}$ & 3.969 .000 & \\
\hline & Pembeli Lain & $\mathrm{Rp}$ & 4.980 .700 & $\mathrm{Rp}$ & 4.980 .700 & \\
\hline \multicolumn{2}{|c|}{ Total } & $\mathrm{Rp}$ & 408.928 .000 & $\mathrm{Rp}$ & 331.510 .000 & Rp 77.418.000 \\
\hline
\end{tabular}

2. Jurnal Pengeluaran Kas

\begin{tabular}{|c|c|c|c|c|c|c|}
\hline \multirow{2}{*}{ Bulan } & \multirow{2}{*}{ Deskripsi } & \multicolumn{3}{|c|}{ Debit } & \multirow{2}{*}{\multicolumn{2}{|c|}{$\begin{array}{l}\text { Kredit } \\
\text { Kas }\end{array}$}} \\
\hline & & Hutang Dagang & Pembelian & & & \\
\hline \multirow{2}{*}{ Jan } & Delima Jaya & & $\mathrm{Rp}$ & 14.108 .000 & $\mathrm{Rp}$ & 14.108 .000 \\
\hline & Maju Jaya & & $\mathrm{Rp}$ & 28.827 .000 & $\mathrm{Rp}$ & 28.827 .000 \\
\hline \multirow{2}{*}{ Feb } & Delima Jaya & & $\mathrm{Rp}$ & 350.000 & $\mathrm{Rp}$ & 350.000 \\
\hline & Maju Jaya & & $\mathrm{Rp}$ & 13.408 .000 & $\mathrm{Rp}$ & 13.408 .000 \\
\hline Maret & Maju Jaya & & $\mathrm{Rp}$ & 13.573 .000 & $\mathrm{Rp}$ & 13.573 .000 \\
\hline \multirow{2}{*}{ April } & Delima Jaya & & $\mathrm{Rp}$ & 2.930 .000 & $\mathrm{Rp}$ & 2.930 .000 \\
\hline & Maju Jaya & & $\mathrm{Rp}$ & 2.616 .000 & $\mathrm{Rp}$ & 2.616 .000 \\
\hline Mei & Maju Jaya & & $\mathrm{Rp}$ & 16.100 .000 & $\mathrm{Rp}$ & 16.100 .000 \\
\hline Juni & Maju Jaya & & $\mathrm{Rp}$ & 2.729 .000 & $\mathrm{Rp}$ & 2.729 .000 \\
\hline Juli & Maju Jaya & & $\mathrm{Rp}$ & 5.325 .500 & $\mathrm{Rp}$ & 5.325 .500 \\
\hline \multirow{2}{*}{ Agst } & Maju Jaya & & $\mathrm{Rp}$ & 1.470 .000 & $\mathrm{Rp}$ & 1.470 .000 \\
\hline & Aneka Elastik & & $\mathrm{Rp}$ & 10.867 .000 & $\mathrm{Rp}$ & 10.867 .000 \\
\hline \multirow{2}{*}{ Sept } & Maju Jaya & & $\mathrm{Rp}$ & 15.086 .000 & $\mathrm{Rp}$ & 15.086 .000 \\
\hline & Aneka Elastik & & $\mathrm{Rp}$ & 1.370 .000 & $\mathrm{Rp}$ & 1.370 .000 \\
\hline Okt & Maju Jaya & & $\mathrm{Rp}$ & 13.984 .000 & $\mathrm{Rp}$ & 13.984 .000 \\
\hline Nop & Maju Jaya & & $\mathrm{Rp}$ & 16.490 .000 & $\mathrm{Rp}$ & 16.490 .000 \\
\hline \multirow{2}{*}{ Des } & \multirow[t]{2}{*}{ Maju Jaya } & & $\mathrm{Rp}$ & 14.852 .000 & $\mathrm{Rp}$ & 14.852 .000 \\
\hline & & $\begin{array}{ll}\mathrm{Rp} & 5.000 .000\end{array}$ & & & $\mathrm{Rp}$ & 5.000 .000 \\
\hline & tal & $\begin{array}{ll}\mathrm{Rp} & 5.000 .000 \\
\end{array}$ & $\mathrm{Rp}$ & 174.085 .500 & $\mathrm{Rp}$ & 179.085 .500 \\
\hline
\end{tabular}

3. jurnal penjualan

\begin{tabular}{|c|c|c|c|c|c|}
\hline \multirow{2}{*}{ Bulan } & \multirow{2}{*}{ Deskripsi } & \multicolumn{2}{|c|}{ Debit } & \multicolumn{2}{|c|}{ Kredit } \\
\hline & & Piut & g Dagang & \multicolumn{2}{|c|}{ Salles } \\
\hline \multirow{2}{*}{ Feb } & Ibu Irah & $\mathrm{Rp}$ & 5.100 .000 & $\mathrm{Rp}$ & 5.100 .000 \\
\hline & Usman & $\mathrm{Rp}$ & 5.686 .000 & $\mathrm{Rp}$ & 5.686 .000 \\
\hline \multirow{2}{*}{ Maret } & Irah & $\mathrm{Rp}$ & 5.266 .000 & $\mathrm{Rp}$ & 5.266 .000 \\
\hline & Usman & $\mathrm{Rp}$ & 1.234 .000 & $\mathrm{Rp}$ & 1.234 .000 \\
\hline \multirow{2}{*}{ April } & Irah & $\mathrm{Rp}$ & 4.707 .000 & $\mathrm{Rp}$ & 4.707 .000 \\
\hline & BUsman & $\mathrm{Rp}$ & 7.701 .500 & $\mathrm{Rp}$ & 7.701 .500 \\
\hline \multirow{3}{*}{ Mei } & Irah & $\mathrm{Rp}$ & 4.349 .000 & $\mathrm{Rp}$ & 4.349 .000 \\
\hline & Usman & $\mathrm{Rp}$ & 5.967 .500 & $\mathrm{Rp}$ & 5.967 .500 \\
\hline & Sodor & $\mathrm{Rp}$ & 6.395 .000 & $\mathrm{Rp}$ & 6.395 .000 \\
\hline \multirow{3}{*}{ Juni } & Irah & $\mathrm{Rp}$ & 4.271 .000 & $\mathrm{Rp}$ & 4.271 .000 \\
\hline & Usman & $\mathrm{Rp}$ & 2.153 .000 & $\mathrm{Rp}$ & 2.153 .000 \\
\hline & Sodor & $\mathrm{Rp}$ & 6.144 .000 & $\mathrm{Rp}$ & 6.144 .000 \\
\hline \multirow{3}{*}{ Juli } & Irah & $\mathrm{Rp}$ & 4.771 .000 & $\mathrm{Rp}$ & 4.771 .000 \\
\hline & Koko & $\mathrm{Rp}$ & 3.913 .000 & $\mathrm{Rp}$ & 3.913 .000 \\
\hline & Sodor & $\mathrm{Rp}$ & 2.680 .000 & $\mathrm{Rp}$ & 2.680 .000 \\
\hline Agst & Koko & $\mathrm{Rp}$ & 1.663 .000 & $\mathrm{Rp}$ & 1.663 .000 \\
\hline \multirow{3}{*}{ Sept } & Fendi & $\mathrm{Rp}$ & 2.900 .000 & $\mathrm{Rp}$ & 2.900 .000 \\
\hline & Koko & $\mathrm{Rp}$ & 2.244 .000 & $\mathrm{Rp}$ & 2.244 .000 \\
\hline & Sodor & $\mathrm{Rp}$ & 800.000 & $\mathrm{Rp}$ & 800.000 \\
\hline \multirow{2}{*}{ Okt } & Fendi & $\mathrm{Rp}$ & 756.000 & $\mathrm{Rp}$ & 756.000 \\
\hline & Koko & $\mathrm{Rp}$ & 2.239 .000 & $\mathrm{Rp}$ & 2.239 .000 \\
\hline Nop & Koko & $\mathrm{Rp}$ & 1.975 .500 & $\mathrm{Rp}$ & 1.975 .500 \\
\hline Des & Irah & $\mathrm{Rp}$ & 4.200 .000 & $\mathrm{Rp}$ & 4.200 .000 \\
\hline \multicolumn{2}{|l|}{ Total } & $\mathrm{Rp}$ & 82.915 .500 & $\mathrm{Rp}$ & 82.915 .500 \\
\hline
\end{tabular}


4. jurnal pembelian

\begin{tabular}{|c|c|c|c|c|}
\hline \multirow{2}{*}{ Bulan } & \multirow{2}{*}{ Deskripsi } & \multirow{2}{*}{\begin{tabular}{|c|} 
Debit \\
Pembelian
\end{tabular}} & \multirow{2}{*}{\multicolumn{2}{|c|}{$\begin{array}{c}\text { Kredit } \\
\text { Hutang Dagang }\end{array}$}} \\
\hline & & & & \\
\hline Jan & \multirow[t]{5}{*}{ Maju Jaya } & 12.907 .000 & & 12.907 .000 \\
\hline Maret & & 3.114 .000 & $\mathrm{Rp}$ & 3.114 .000 \\
\hline April & & 1.656 .000 & $\mathrm{Rp}$ & 1.656 .000 \\
\hline Agst & & 3.812 .000 & $\mathrm{Rp}$ & 3.812 .000 \\
\hline Des & & 3.840 .000 & $\mathrm{Rp}$ & 3.840 .000 \\
\hline
\end{tabular}

SAK-ETAP and

Financial

Performance

\section{c. Pemindahbukuan}

UMKM Toko Angka Wijaya tidak melakukan pemindahbukuan akun-akun kedalam buku besar. Maka dilakukan pemindahbukuan ke dalam buku besar dengan memindahkan akun-akun yang sama pada jurnal ke dalam buku besar

\section{UMKM Toko Angka Wijaya}

BUKU BESAR UTAMA

Desember 2018

1. Kas

\begin{tabular}{|c|c|c|c|c|c|c|}
\hline \multirow[b]{2}{*}{ Deskripsi } & \multirow[b]{2}{*}{ Debit } & & \multirow[b]{2}{*}{ Kredit } & \multicolumn{3}{|c|}{ Saldo } \\
\hline & & & & Debit & & Kredit \\
\hline Jurnal Penerimaan Kas & Rp 430.945.500 & & & Rp 430.945.500 & & \\
\hline Jurnal Pengeluarankas & & $\mathrm{Rp}$ & 179.085 .500 & Rp 251.860.000 & & \\
\hline \multicolumn{7}{|l|}{ 2. Penjualan } \\
\hline \multirow{2}{*}{ Deskripsi } & \multirow{2}{*}{ Debit } & \multirow{2}{*}{\multicolumn{2}{|c|}{ Kredit }} & \multicolumn{3}{|c|}{ Saldo } \\
\hline & & & & Debit & & Kredit \\
\hline Jurnal Penerimaan Kas & & & 353.528 .000 & & $\mathrm{Rp}$ & 353.528 .000 \\
\hline Jurnal Penjualan & & $\mathrm{Rp}$ & 86.315 .500 & & $\mathrm{Rp}$ & 439.843 .500 \\
\hline \multicolumn{7}{|l|}{ Pembelian } \\
\hline \multirow{2}{*}{ Deskripsi } & \multirow{2}{*}{ Debit } & & \multirow{2}{*}{ Kredit } & \multicolumn{3}{|c|}{ Saldo } \\
\hline & & & & Debit & & Kredit \\
\hline Jurnal Pengeluaran Kas & Rp 174.085 .500 & & & Rp 174.085.500 & & \\
\hline Jurnal Pembelian & 3.840 .000 & & & Rp 177.925.500 & & \\
\hline
\end{tabular}

UMKM Toko Angka Wijaya

BUKU BESAR PEMBANTU PIUTANG DAGANG

Desember 2018

\begin{tabular}{|c|c|c|c|c|c|}
\hline \multirow{2}{*}{ Bulan } & \multirow{2}{*}{ Deskripsi } & \multirow{2}{*}{ Debit } & \multirow{2}{*}{ Kredit } & \multicolumn{2}{|c|}{ Saldo } \\
\hline & & & & Debit & Kredit \\
\hline Februari & Jurnal Penjualan & Rp 5.100.000 & & & Rp5.100.000 \\
\hline Maret & & Rp 5.266.000 & & & $\mathrm{Rp} 5.266 .000$ \\
\hline April & & $\mathrm{Rp} 4.707 .000$ & & & $\mathrm{Rp} 4.707 .000$ \\
\hline Mei & & $\mathrm{Rp} 4.349 .000$ & & & Rp 4.349.000 \\
\hline Juni & & Rp 4.271.000 & & & $\mathrm{Rp} 4.271 .000$ \\
\hline Juli & & Rp 4.771.000 & & & Rp 4.771 .000 \\
\hline Desember & & Rp 4.200.000 & & & Rp 4.200 .000 \\
\hline 30-Des-18 & J. Penerimaan Kas & & 32.664 .000 & & $\mathrm{Rp}$ \\
\hline
\end{tabular}

\begin{tabular}{|c|c|c|c|c|c|}
\hline \multicolumn{6}{|c|}{ Bapak Fendi } \\
\hline \multirow{2}{*}{ Bulan } & \multirow{2}{*}{ Deskripsi } & \multirow[t]{2}{*}{ Debit } & \multirow[t]{2}{*}{ Kredit } & \multicolumn{2}{|c|}{ Saldo } \\
\hline & & & & Debit & Kredit \\
\hline September & J. Penerimaan Kas & & Rp 500.000 & & Rp 500.000 \\
\hline September & Jurnal Penjualan & Rp 2.900.000 & & Rp 2.400.000 & \\
\hline Oktober & & $\begin{array}{ll}\mathrm{Rp} & 756.000 \\
\end{array}$ & & $\operatorname{Rp} 3.156 .000$ & \\
\hline Desember & J. Penerimaan Kas & & $\operatorname{Rp} 2.000 .000$ & $\operatorname{Rp} 1.156 .000$ & \\
\hline
\end{tabular}

3. Bapak Usman

\begin{tabular}{|c|c|c|c|c|c|}
\hline \multirow{2}{*}{ Bulan } & \multirow{2}{*}{ Deskripsi } & Debit & \multirow{2}{*}{ Kredit } & \multicolumn{2}{|c|}{ Saldo } \\
\cline { 5 - 6 } & & & & Debit & Kredit \\
\hline Februari & Jurnal Penjualan & $\mathrm{Rp} \mathrm{5.686.000}$ & & $\mathrm{Rp} 5.686 .000$ & \\
\hline Maret & Jurnal Penjualan & $\mathrm{Rp} 1.234 .000$ & & $\mathrm{Rp} 6.920 .000$ & \\
\hline April & Jurnal Penjualan & $\mathrm{Rp} \mathrm{7.701.500}$ & & $\mathrm{Rp} 14.621 .500$ & \\
\hline Mei & Jurnal Penjualan & $\mathrm{Rp} \mathrm{5.967.500}$ & & $\mathrm{Rp} \mathrm{20.589.000}$ & \\
\hline Juni & Jurnal Penjualan & $\mathrm{Rp} 2.153 .000$ & & $\mathrm{Rp} \mathrm{22.742.000}$ & \\
\hline Juni & J. Penerimaan Kas & & $\mathrm{Rp} 15.000 .000$ & $\mathrm{Rp} 7.742 .000$ & \\
\hline
\end{tabular}

4. Bapak Koko
\begin{tabular}{|c|l|c|c|c|c|}
\hline \multirow{2}{*}{ Bulan } & Deskripsi & Debit & \multirow{2}{*}{ Kredit } & \multicolumn{2}{|c|}{ Saldo } \\
\cline { 5 - 6 } & & & & Debit & Kredit \\
\hline Juli & Jurnal Penjualan & Rp 3.913 .000 & & $\mathrm{Rp} 3.913 .000$ & \\
\hline Agst & Jurnal Penerimaan Kas & $\mathrm{Rp} 1.663 .000$ & & $\mathrm{Rp} 5.576 .000$ & \\
\hline Sept & Jurnal Penerimaan Kas & $\mathrm{Rp} 2.244 .000$ & & $\mathrm{Rp} 7.820 .000$ & \\
\hline Okt & Jurnal Penerimaan Kas & $\mathrm{Rp} 2.239 .000$ & & $\mathrm{Rp} 10.059 .000$ & \\
\hline Nop & Jurnal Penerimaan Kas & $\mathrm{Rp} 1.975 .500$ & & $\mathrm{Rp} 12.034 .500$ & \\
\hline Des & Jurnal Penerimaan Kas & & $\mathrm{Rp} 12.034 .500$ & $\mathrm{Rp}$ & - \\
\hline
\end{tabular}

JADKES

Jurnal Abdimas Dedikasi Kesatuan Vol. 1 No. 1,2020 pp. 11-20 IBI KESATUAN E-ISSN XXXX - XXXX DOI: 10.374 
$S A K-E T A P$ and Financial Performance

5. Bapak Sodor

5.
\begin{tabular}{|c|c|c|c|c|c|}
\hline \multirow{2}{*}{ Bulan } & Deskripsi & Debit & Kredit & \multicolumn{2}{|c|}{ Saldo } \\
\cline { 3 - 6 } & & & & Debit & Rp 6.395 .000 \\
\hline Mei & Jurnal Penjualan & Rp 6.395 .000 & & Rp 12.539 .000 & \\
\hline Juni & Jurnal Penjualan & Rp 6.144 .000 & & & Rp 2.680 .000 \\
\hline Juli & J. Penerimaan Kas & & Rp 15.219 .000 & & Rp \\
\hline Juli & Jurnal Penjualan & Rp 2.680.000 & & Rp 800.000 & \\
\hline Sept & Jurnal Penjualan & Rp 800.000 & & \\
\hline
\end{tabular}

UMKM Toko Angka Wijaya

BUKU BESAR PEMBANTU HUTANG DAGANG

Desember 2018

\begin{tabular}{|c|c|c|c|c|c|c|}
\hline \multirow{2}{*}{ Bulan } & \multirow{2}{*}{ Deskripsi } & \multirow{2}{*}{ Debit } & \multirow{2}{*}{\multicolumn{2}{|c|}{ Kredit }} & \multicolumn{2}{|r|}{ Saldo } \\
\hline & & & & & Debit & Kredit \\
\hline Jan & \multirow{5}{*}{$\begin{array}{l}\text { Jurnal } \\
\text { Pembelian }\end{array}$} & & $\mathrm{Rp}$ & 12.907 .000 & & Rp 12.907 .000 \\
\hline Maret & & & $\mathrm{Rp}$ & 3.114 .000 & & Rp 16.021 .000 \\
\hline April & & & $\mathrm{Rp}$ & 1.656 .000 & & $\begin{array}{ll}\mathrm{Rp} & 17.677 .000\end{array}$ \\
\hline Agst & & & $\mathrm{Rp}$ & 3.812 .000 & & Rp 21.489 .000 \\
\hline Des & & & $\mathrm{Rp}$ & 3.840 .000 & & Rp 25.329 .000 \\
\hline 30-Des & J. Penerimaan Kas & Rp 5.000 .000 & & & & $\mathrm{Rp} \quad 20.329 .000$ \\
\hline
\end{tabular}

\section{Siklus Akuntansi Pada akhir periode}

a. Menyusun laporan keuangan

UMKM Toko Angka Wijaya tidak menerapkan laporan keuangan atas kegiatan usahanya.

Untuk itu berikut adalah laporan keuangan yang penulis susun berdasarkan SAK ETAP :

1. Neraca, merupakan aspek penting bagi UMKM untuk mengatahui informasi mengenai aset, kewajiban dan ekuitas UMKM. Berikut adalah penerapan neraca berdasarkan SAK-ETAP:

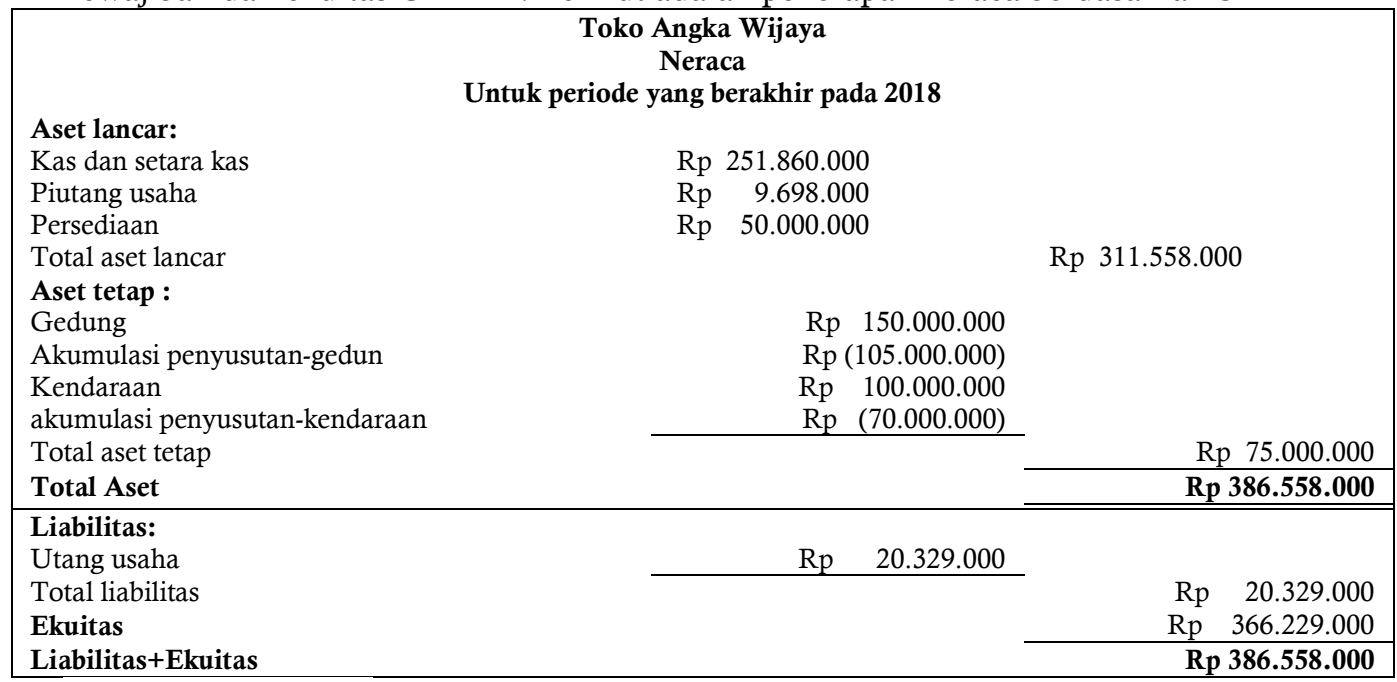

2. Laporan Laba Rugi, memberikan informasi mengenai pendapatan dari penjualan juga bebanbeban yang dikeluarkan selama satu periode. Berikut adalah penyusunan Laporan Laba Rugi berdasarkan SAK-ETAP:

Penjualan

HPP

Laba Kotor

Beban penjualan :

Beban gaji pegawai

Beban depresiasi-gedung

Beban depresiasi-kendaraan

Beban administrasi :

Beban listrik

Beban telpon

Total beban

Laba bersih

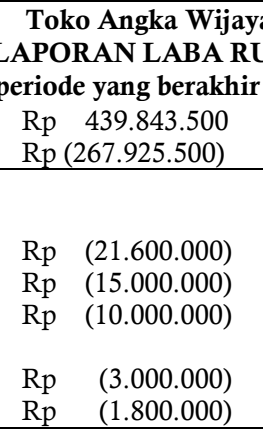

Toko Angka Wijaya

Rp $\quad 439.843 .500$

$\mathrm{Rp}(267.925 .500)$

$\mathrm{Rp} \quad(21.600 .000)$

Rp (15.000.000)

$\operatorname{Rp} \quad(10.000 .000)$

Rp (3.000.000)

$\mathrm{Rp} \quad(1.800 .000)$

LAPORAN LABA RUGI

Untuk periode yang berakhir pada 2018

$\mathrm{Rp} \quad 171.918 .000$ 
3. Laporan Perubahan Ekuitas

Laporan perubahan menyajikan laba atau rugi entitas untuk suatu periode. Berikut adalah penerapan Laporan Perubahan berdasarkan SAK-ETAP:

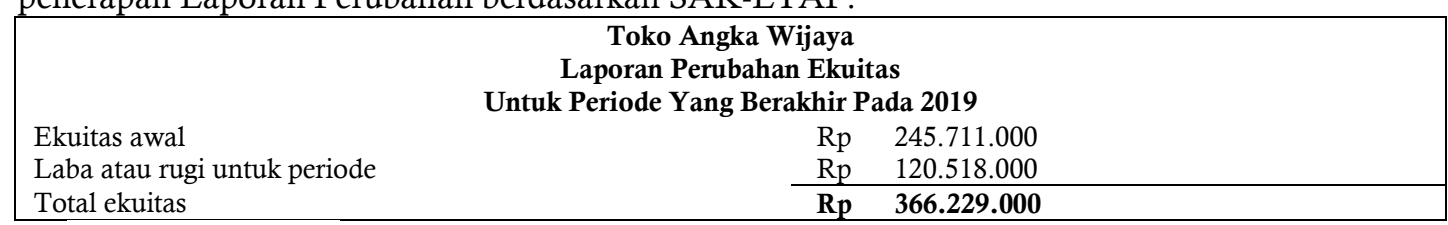

4. Laporan Arus Kas

Laporan arus kas menyajikan informasi perubahan historis atas kas dan setara kas entitas, yang menunjukan secara terpisah perubahan yang terjadi selama satu periode dari aktivitas oprasi, investasi, dan pendanaan. Berikut penerapan Laporan Arus Kas berdasarkan SAK ETAP:

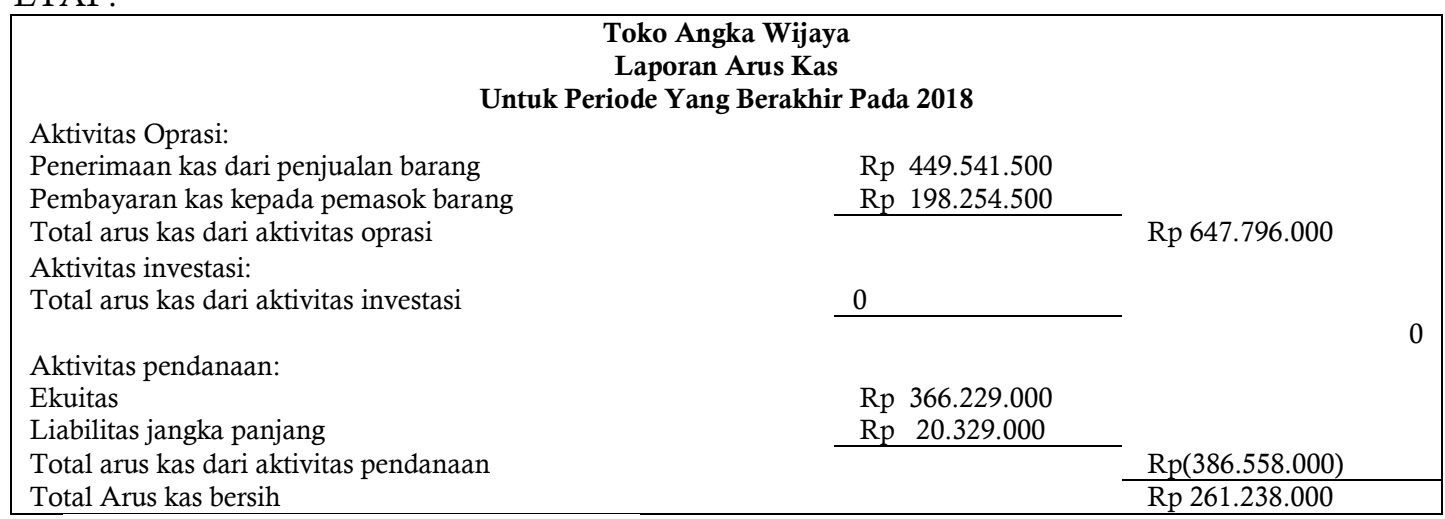

5. Catatan Atas Laporan Keuangan

Catatan atas laporan keuangan akan membantu UMKM dalam mencatat hal-hal yang tidak diungkapkan dalam laporan keuangan yang telah disusun. Berikut adalah catatan atas laporan keuangan berdasarkan SAK-ETAP :

\section{Toko Angka Wijaya \\ CATATAN ATAS LAPORAN KEUANGAN \\ Untuk Periode Yang Berakhir Pada 2018}

\section{Gambaran Umum}

UMKM Toko Angka Wijaya merupakan suatu usaha yang bergerak dibidang perdagangan yang berdiri sejak tahun 2011. UMKM ini beralamat di Jl. Endang Sumawijaya Kampung Sindang Barang Desa Pasir Eurih Kecamatan Taman Sari Kabupaten Bogor

\section{Penyusunan Laporan Keuangan}

Penyusunan laporan keuangan pada UMKM Toko Angka Wijaya menggunanakan Standar Akuntansi Keuangan Entitas Tanpa Akuntabilitas Publik (SAK-ETAP) dan dicatat menggunakan sistem accrual basis. Untuk laporan arus kas menggunakan metode tidak langsung

3. Kebijakan Akuntansi

Kebijakan akuntansi pada UMKM Toko Angka Wijaya adalah sebagai berikut:

a. Dasar pengukuran

Dasar pengukuran yang digunakan dalam penyusunan laporan keuangan menggunakan biaya historis dimana aset yang dimiliki oleh UMKM Toko Angka Wijaya dicatat UMKM sebesar keluarnya kas yang dibayar

b. Kas dan setara kas

Kas dan setara kas yang dimiliki oleh UMKM Toko Angka Wijaya terdapat di tangan dan di simpan di bank. Kas di tangan digunakan untuk biaya oprasional sehari-hari seperti pembayaran biaya angkut pengiriman, pembayaran listrik dan biaya oprasional lainnya dalam jumlah yang kurang dari RP 500.000. Kas di bank digunakan untuk kegiatan oprasional dalam jumlah besar seperti pembayaran gaji karyawan dan pembelian persediaan barang dagang atau yang jumlahnya lebih dari $\mathrm{Rp} 500.000$

c. Metode penyusutan

Metode penyusutan aset tetap pada UMKM Toko Angka Wijaya menggunakan metode garis lurus 
SAK-ETAP and

Financial

Performance

d. Pendapatan dan beban

Pendapatan UMKM Toko Angka Wijaya langsung diakui sebagai pendapatan yaitu pada saat barang dagang dibeli oleh pembeli atau saat barang dagang dikirim kepada pembeli dan untuk beban diakui sesuai masa manfaat pada periode bersangkutan

e. Hutang usaha

Hutang usaha yang di miliki oleh UMKM Toko Angka Wijaya berasal dari pembelian persediaan barang dagang sebesar $\mathrm{Rp} 20.329 .000$ kepada toko maju jaya

f. Ekuitas

Ekuitas berasal dari modal pribadi pemilik UMKM Toko Angka Wijaya

\section{8}

\section{JADKES}

Jurnal Abdimas Dedikasi Kesatuan

Vol. 1 No. 1,2020

pp. $11-20$

IBI KESATUAN

E-ISSN XXXX - XXXX

DOI:

\section{Hasil kinerja Keuangan UMKM Toko Angka Wijaya}

Setelah laporan keuangan disusun selanjutnya menganalisis kinerja keuangan UMKM Toko Angka Wijaya. Tolak ukur yang dapat digunakan untuk menilai kinerja keuangan suatu perusahaan adalah rasio keuangan. Rasio keuangan yang digunakan untuk menganalisis kinerja keuangan UMKM Angka Wijaya adalah rasio profitabilitas. Maka berikut adalah hasil kinerja keuangan dengan menggunakan rasio profitabilitas UMKM Angka Wijaya :

a. Gross Profit Margin

Gross profit margin menurut Kasmir $(2013 ; 199)$ adalah margin laba kotor atas penjualan. Berikut adalah hasil perhitungan gross profit margin UMKM Toko Angka Wijaya:

$\begin{aligned} & \text { Laba Kotor } \\ & \text { Penjualan }\end{aligned}=\frac{R p}{R p}=39,09 \%$

Gross profit margin UMKM Toko Angka Wijaya pada tahun 2018 menunjukan angka $39,09 \%$ Artinya jumlah laba kotor yang diperoleh UMKM sejumlah 39,09\% dari jumlah penjualan UMKM dalam satu periode atau setiap Rp 1 penjualan berkontribusi memberikan 0,39 laba kotor. Menurut Kasmir (2013:134) standar gross profit margin dapat dikatakan baik jika menunjukan angka $30 \%$ dan jika angka menunjukan $>30 \%$ dapat dikatakan sangat baik. Maka gross profit margin UMKM Toko Angka Wijaya dapat dikatakan sangat baik. Hal ini dikarenakan harga pokok penjualan cenderung lebih rendah dibandingkan dengan harga penjualan.

b. Net Profit Margin

Berikut adalah hasil perhitungan net profit margin UMKM Toko Angka Wijaya:

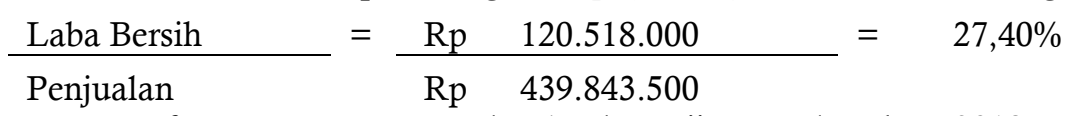

Net profit margin UMKM Toko Angka Wijaya pada tahun 2018 menujukan angka 27,40\%. Artinya laba bersih yang diperoleh UMKM sebesar 27,40\% dari jumlah penjualan UMKM atau setiap Rp 1 dari penjualan menghasilkan 0,27 laba bersih. Menurut Kasmir (2013;134) standar net profit margin dapat dikatakan baik jika menunjukan angka $20 \%$ dan jika angka menunjukan $>20 \%$ dapat dikatakan sangat baik. Maka net profit margin UMKM Toko Angka Wijaya dapat dikatakan sangat baik. Hal ini dikarenakan entitas tersebut sudah baik dalam menjalakan kegiatan operasi penjualan nya

c. Return On Asset

Berikut adalah hasil perhitungan return on asset UMKM Toko Angka Wijaya:

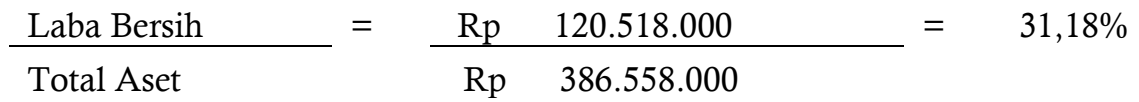

Return on asset UMKM Toko Angka Wijaya pada tahun 2018 menunjukan angka 31,18\% . Artinya laba bersih yang diperoleh UMKM dari total aset sebesar $31,18 \% \%$ atau setiap Rp 1 aset berkontribusi menciptakan 0,31 laba bersih. Menurut Kasmir $(2013 ; 134)$ standar return on asset dapat dikatakan baik jika menunjukan angka 30\% dan jika angka menunjukan $>30 \%$ dapat dikatakan sangat baik. Maka return on asset UMKM Toko Angka Wijaya dapat dikatakan baik. Hal ini dikarenakan kinerja UMKM Toko Angka Wijaya sudah efisien dalam penggunaan aset untuk menghasilkan laba operasi bersih Toko Angka Wijaya, karena return on asset akan baik jika suatu entitas efisien dalam penggunaan aset untuk menghasilkan laba

d. Return On Equity

Berikut adalah hasil perhitungan return on equity UMKM Toko Angka Wijaya:

\begin{tabular}{|c|c|c|c|}
\hline Laba Bersih & $\mathrm{Rp}$ & 120.518 .000 & $=$ \\
\hline Total Ekuitas & $\mathrm{Rp}$ & 366.229 .000 & \\
\hline
\end{tabular}


Return on equity UMKM Toko Angka Wijaya pada tahun 2018 menujukan angka 32,91\%. Artinya laba bersih yang diperoleh perusahaan sebesar $32,91 \%$ dari modal UMKM atau setiap Rp 1 daro total ekuitas berkontribusi menciptakan 0,32 laba bersih. Menurut Kasmir (2013:134) standar return on equity dapat dikatakan baik jika menunjukan angka $40 \%$ dan jika menunjukan angka $>40 \%$ dapat dikatakan sangat baik. Maka return on equity UMKM Toko Angka Wijaya dapat dikatakan tidak baik. Hal ini dikarenakan UMKM Toko Angka Wijaya belum mampu mengelola modalnya secara efisien, karena return on equity akan baik jika entitas mampu mengelola modalnya secara efisien.

\section{PENUTUP}

Berdasarkan hasil pendampingan dan pembahasan yang telah disajikan sebelumnya, maka dapat ditarik kesimpulan sebagai berikut:

1. UMKM toko angka wijaya tidak menerapkan laporan keuangan berdasarkan SAK ETAP, pemilik UMKM hanya melakukan pencatatan keuangan sederhana dalam kegiatan usahanya. Hal ini dikarenakan pemilik UMKM Toko angka wijaya tidak mengerti laporan keuangan berdasarkan SAK ETAP dan ketidakmampuan pemilik UMKM dalam membayar tenaga ahli akuntan. Berdasarkan hasil penelitian selama tahun 2018 dapat dihasilkan neraca umkm toko angka wijaya sebesar Rp 386.558.000, laba sebesar Rp 120.518.000 ekuitas sebesar Rp 366.229 .000 dan total arus kas bersih sebesar Rp 261.238.000

2. Hasil kinerja UMKM toko angka wijaya yang dihitung dengan menggunakan rasio profitabilitas berdasarkan perolehan laba dari hasil penjualan dan dari total aset yang digunakan sudah termasuk dalam kriteria baik artinya UMKM toko angka wijaya sudah baik dalam hal penjualan dan sudah efisien dalam penggunaan aset, sedangkan kinerja UMKM dalam perolehan laba berdasarkan pengunaan modal kurang baik hal ini dikarenakan UMKM toko angka wijaya kurang efisien dalam penggunaan modal

\section{DAFTAR PUSTAKA}

Amaefule, Leonard I., Onyekpere, Ulumma R., and Kalu, Edith O. 2018. International Financial Reporting Standards and Manufacturing Firms' Financial Performance in Nigeria: A Study of Selected Quoted Firms. International Journal of Accounting and Taxation. Vol.6(1):103-114

Ferdinan giri, efraim., 2012. Akuntansi Keuangan Menenah 1 Perspekif IFRS , UPP STIM YKPN , Jakarta

Iriyadi, I., 2019. Prevention of Earnings Management through Audit Committee and Audit Quality in the Award-Winning and Non-Winning Companies. Journal of Accounting Research, Organization and Economics, 2(2), pp.155-169.

Ikatan Akuntansi Indonesia. 2012. Standar Akuntansi Keuangan PSAK No.1, Dewan Standar Akuntansi Keuangan, Jakarta

Ikatan Akuntansi Indonesia. 2013. Standar Akuntansi Keuangan Entitas Tanpa Akuntabilitas Publik, Dewan Standar Akuntansi Keuangan, Jakarta

Kartikahadi, Hans., 2012. Akutansi Keuangan Berdasarkan SAK berbasis IFRS, Salemba 4,Jakarta.

Kasmir., 2013. Analisis Laporan keuangan,Rajawali pers,jakarta

Kementerian Koperasi dan UMKM Republik Indonesia. [internet]. [diakses pada 3 agustus 2018]. Tersedia pada: http://www.depkop.go.id/berita-informasi/datainformasi/data-umkm/

Kieso, D.E., Weygandt, J.J., and Warfield, T.D., 2010. Intermediet Accounting:IFRS Edition Volume I,John Wiley\&Son, United States of America

Kembauw, E., Munawar, A., Purwanto, M.R., Budiasih, Y. and Utami, Y., 2020. Strategies of Financial Management Quality Control in Business. Manfacturers' Capital Structure.
SAK-ETAP and

Financial

Performance

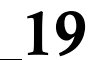


SAK-ETAP and Financial Performance

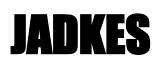

Jurnal Abdimas Dedikasi Kesatuan

Vol. 1 No. 1, 2020 pp. 11-20

IBI KESATUAN E-ISSN XXXX - XXXX DOI:
Mulyana, M., Hidayat, L. and Puspitasari, R., 2019. Mengukur Pengetahuan Investasi Para Mahasiswa Untuk Pengembangan Galeri Investasi Perguruan Tinggi. JAS-PT (Jurnal Analisis Sistem Pendidikan Tinggi Indonesia), 3(1), pp.31-52.

Mackenzie, bruce., 2012. IFRS For Smes Untuk Usaha Kecil Menegah Atau Entitas Tanpa Akuntabilitas Publik,PT. Indek, Jakarta.

Nurlela dan Elvia, heny., 2016. Penerapan Laporan Keuangan Usaha Kecil Menengah Berbasis Sak Etap Pada Toko Jamu Nikisami. Jurnal Bisnis Administrasi. Vol.5(2):60-66

Nulla, yusuf mohammed., 2014. Does IFRS Adoption Influence Quality of Reporting?: An Empirical Evidence from Large Canadian Banks. International Journal of Accounting and Taxation. Vol.2(2):85-109

Pamungkas, B., 2005. Evaluasi Penerapan Akuntansi Pertanggungjawaban dalam Penilaian Kinerja Studi Kasus pada PT. Sierad Produce Tbk. Jurnal Ilmiah Ranggagading (JIR), 5(2), pp.85-91.

Pamungkas, B., Ibtida, R. and Avrian, C., 2018. Factors influencing audit opinion of the Indonesian municipal governments' financial statements. Cogent Business \& Management, 5(1), p.1540256.

Purba, J.H.V. and Magdalena, A., 2017. Pengaruh Nilai Tukar Terhadap Ekspor dan Dampaknya Terhadap Pertumbuhan Ekonomi Indonesia. DeReMa Jurnal Manajemen, 12(2), pp.285-295.

Purba, J.H.V., Ratodi, M., Mulyana, M., Wahyoedi, S., Andriana, R., Shankar, K. and Nguyen, P.T., 2019. Prediction Model in Medical Science and Health Care. International Journal of Engineering and Advanced Technology, 8, pp.815-818.

Presiden Republik Indonesia., 2008. Undang-Undang Republik Indonesia Nomor 20 Tentang Usaha Mikro, Kecil, Dan Menengah.

Putri, D.S. and Muktiadji, N., 2017. Analisis Portfolio Optimal Pada Beberapa Perusahaan LQ-45 Komparasi Pendekatan Markowits Dan Model Indeks Tunggal. Jurnal Ilmiah Manajemen Kesatuan, 5(1), pp.33-43.

Rusdiyana, R. and Munawar, A., 2012. ANALISIS PENGELOLAAN AKTIVA TERHADAP KINERJA PENDAPATAN PER LEMBAR SAHAM (EPS). Jurnal Online Mahasiswa-Manajemen, 1(2).

Sulistiono, S., Nurendah, Y. and Mulyana, M., 2019. Mengukur Minat Studi Siswa SMA dan SMK di Kota Bogor Pada Program Studi Kewirausahaan. JAS-PT (Jurnal Analisis Sistem Pendidikan Tinggi Indonesia), 3(1), pp.1-12.

Susilawati, N. and Supriadi, Y., 2017. Pengaruh Cash Ratio dan Siklus Konversi Kas Terhadap Profitabilitas Perusahaan. Jurnal Ilmiah Manajemen Kesatuan, 5(2), pp.115-124.

Sudana, i made., 2011. Manajemen Keuangan Perusahaan Teori dan Praktik,Penerbit erlangga, Jakarta.

Sugiyono., 2013. Metode Penelitian Kuantitatif, Kualitatif Dan R\&D, CV. Alfabeta, Bandung

Silalahi, Ulber., 2012. Metode Penelitian Sosial, Refika Aditama, Bandung

Syamsudin, Lukman., 2011. Manajemen Keuangan Perusahaan, Rajawali pers, Jakarta

Wantah, Marshallino Jordy. 2015. Analisis Penerapan Psak No.1 Tentang Penyajian Laporan Keuangan Pada Perum Bulog Divre Sulut Dan Gorontalo. Jurnal Berkala Ilmiah Efisiensi. Vol.15(4):74-88

Warsadi, Ketut Ari., herawati, nyoman trisna dan julianto, putu. 2017. Penerapan Penyusunan Laporan Keuangan Pada Usaha Kecil Menengah Berbasis Standar Akuntansi Keuangan Entitas Mikro, Kecil, Dan Menengah Pada Pt. Mama Jaya. Jurusan Akuntansi Program S1, Vol.8(2):11-20

Wijaya, david. 2018. Akuntansi UMKM,penerbit gava media, Yogyakarta 